\title{
Erratum to: Phylogeny and Classification of Gibbons (Hylobatidae)
}

\author{
Christian Roos
}

\section{Erratum to:}

Chapter 7 in: U.H. Reichard et al. (eds.), Evolution of Gibbons and Siamang, Developments in Primatology: Progress and Prospects, 10.1007/978-1-4939-5614-2_7

The book was inadvertently published without the placement of the first part of the figure in Fig. 7.2. The erratum book has been updated with the correction.

The updated original online version for this chapter can be found at 10.1007/978-1-4939-5614-2_7

C. Roos ( $\square)$

Gene Bank of Primates, Primate Genetics Laboratory, German Primate Center,

Leibniz Institute for Primate Research, Kellnerweg 4, 37077 Göttingen, Germany

e-mail: croos@dpz.eu 